\title{
Expansion of 'Red Corridor' in Jangalmahal : A Demand for Ethical Justice
}

\author{
Md. Iqbal Sultan \\ Research Scholar, Dept. of Geography, University of Calcutta, India
}

\begin{abstract}
The South-Western part of West Bengal including a major part of West Midnapore, Bankura and Purulia District (approx. latitude $21^{\circ} 45^{\prime} N$ to $23^{\circ} 45^{\prime} N \& 85^{\circ} 45^{\prime} E$ to $87^{\circ} 30^{\prime} E$ ) is now literary marked as 'Jangalmahal'. The name says that the major part of this region is covered by forest or jungle and it is one of the socio-economically backward regions of West Bengal. Ethnical variation of the region is also remarkable. Almost 25-30\% of the total population of the aforesaid districts is tribes. Now-a-days the uprising Maoist Movement ('Terrorism' according to the State) creates a new sociopolitical dimension in West Bengal. Apparently, the reason behind this is the backwardness and historical deprivation of an ethnical group. But it is not the only reason. The various reasons lying behind this also include their demand for cultural identity. So, the movement is now gradually turning to cultural and political movement against the upper caste (the so-called mainstream) who historically and hereditary enjoys all powers of a state. The recent tug-of-war of the political parties in West Bengal has made the situation more critical. The problem may only be mitigated humanistically, not politically. The main aim of this paper is to discuss the cause, consequence and lastly the solution of the problem in the light of Geographical, Ethnological and Philosophical aspect keeping aside the traditional political debate. Besides the theoretical description, some maps and cartograms have also been used to justify the analysis.

(key words : Jangalmahal, Maoist Movement, Ethnical variation, Cultural identity)
\end{abstract}

\section{Introduction}

Terrorism is a systematic use of terror or unpredictable violence against governments, publics, or individuals to attain a political objective. It has been used by the political organisations with both rightist and leftist objectives, by nationalistic and ethnic groups, by revolutionaries, and by the armies and secret police of governments themselves. The U.S. Code of Federal Regulations defines terrorism in the U.S. as : The unlawful use of force and violence against persons or property to intimidate or coerce a government, the civilian population, or any segment thereof, in furtherance of political or social objectives.

Now-a-days the uprising Maoist Movement ('Terrorism' according to the state) [1] creates a new socio-political dimension in West Bengal. Apparently, the reason behind this is the backwardness and historical deprivation of an ethnical group. But it is not the only reason. The various reasons lying behind this also include their demand for cultural identity[2]. So, the movement is now gradually turning to cultural and political movement against the upper caste (the so-called mainstream) who historically enjoys all powers of a state. The recent tug-of-war of the political parties in West Bengal has made the situation more critical. The problem may only be mitigated humanistically, not politically.

\section{Objectives}

The main objectives of this paper are

a) To focus on present socio-cultural as well as economic scenario of the Jangalmahal;

b) To find out the historical and ethnological background of the deprivation of the tribal community;

c) Cause and effect analysis of the unrest situation of the respective region in the light of geography, ethnography and philosophy, keeping aside the traditional political debate;

d) Some suggestion on geographical perspective to overcome or mitigate the problem.

\section{Database And Methodology}

This is mainly a descriptive or analytical paper. The information have been collected from various books, scholarly articles, newspaper, journals and reliable websites. Some maps, diagrams and graphs have been used to justify the theoretical analysis. 


\section{The Study Area}

The western part of South Bengal including a major part of West Midnapore, Bankura and Purulia District (approx. latitude $21^{0} 45^{\prime} \mathrm{N}$ to $23^{\circ} 45^{\prime} \mathrm{N} \& 85^{\circ} 45^{\prime} \mathrm{E}$ to $87^{0} 30^{\prime} \mathrm{E}$ ) is now literary marked as 'Jangalmahal'. The name says that the major part of this region is covered by forest or jungle and now a days the socio-economically backward region is strongly Maoist affected. Among the twenty seven blocks of West Midnapore District twenty are extremely Maoist influenced (i.e. Jhargram, Jamboni, Lalgarh, Belpahari, Sankrail etc). A major part of Purulia District also exists under Jangalmahl. Among the twenty one blocks twelve are found in increasing Maoist activities (i.e. Manbazar | \& ||, Arsha, Ragunathpur, Banduan, Balarampur and Baghmundi etc). Now a days the Maoist activity is gradually increasing at the remote blocks of Bankura District which are mainly located in the Southern part of the district (i.e. Ranibandh, Raipur I \& II and Simlapal etc).

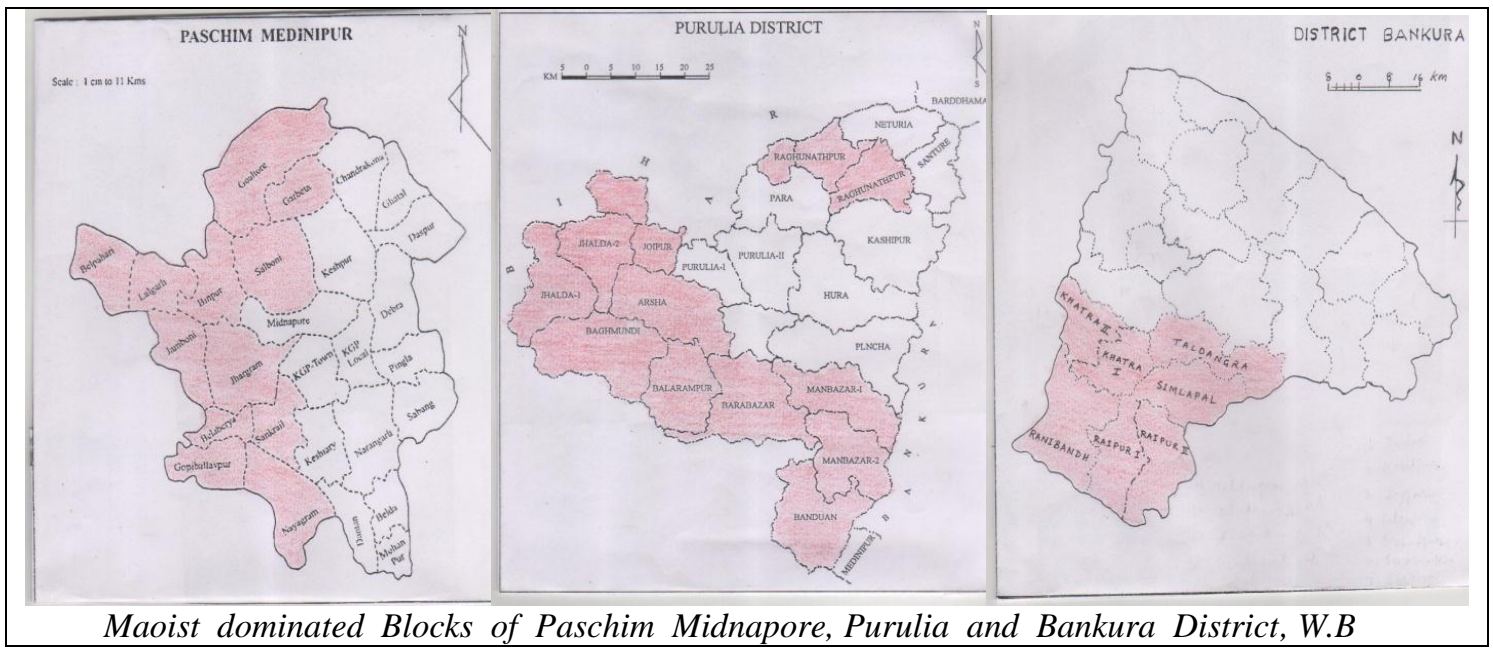

\section{A Brief History Of Far-Left Radical Communist Movement In West Bengal}

The word Naxal, Naxalite or Naksalvadi is a generic term used to refer to various militant Communist groups operating in different parts of India under different organizational envelopes. In the eastern states of the mainland India (Bihar, West Bengal and Orissa), they are usually known as, or refer to themselves as Maoists [3].

The term Naxalites comes from Naxalbari, a small village in West Bengal, where a section of the Communist Party of India (Marxist) (CPM) led by Charu Majumdar, Kanu Sanyal and Jangal Santhal initiated a violent uprising in 1967. Charu Majumdar, inspired by the doctrines of Mao Zedong, provided Ideological leadership for the Naxalbari movement, advocating that Indian peasants and lower class tribals overthrow the government and upper classes by force. A large number of urban elites were also attracted to the ideology, which spread through Majumdar's writings, particularly the 'Historic Eight Documents' which formed the basis of Naxalite ideology. In 1967, Naxalites organised the All India Coordination Committee of Communist Revolutionaries (AICCCR), and later broke away from CPM. Violent uprisings were organised in several parts of the country. In 1969, the AICCCR gave birth to the Communist Party of India (MarxistLeninist) (CPI(ML). During the 1970s, the movement was fragmented into disputing factions. By 1980, it was estimated that around 30 Naxalite groups were active, with a combined membership of 30,000 [4].

The Naxalites gained a strong presence among the radical sections of the student movement in Calcutta. Students left school to join the Naxalites. Majumdar, to entice more students into his organisation, declared that revolutionary warfare was to take place not only in the rural areas as before, but everywhere and spontaneously. Thus Majumdar declared an "annihilation line", a dictum that Naxalites should assassinate individual "class enemies" such as landlords, businessmen, university teachers, police officers, politicians of both Right and Left) and others. The Chief Minister, Siddhartha Shankar Ray of the Congress Party, instituted strong counter-measures against the Naxalites. The West Bengal police fought back to stop the Naxalites.

Large sections of the Naxal movement began to question Majumdar's leadership. In 1971 the CPI(ML) was split, as the Satyanarayan Singh revolted against Majumdar's leadership. In 1972 Majumdar was arrested by the police and died in Alipore Jail. His death accelerated the fragmentation of the movement [5]. 


\section{Recent Lalgarh Movement}

In late May, 2009 In Lalgarh, West Midnapore the Naxalites briefly threw out the local police and staged attacks against the ruling communist government. The region came under assault by Maoist guerrillas. The state government initiated a successful operation, with central paramilitary forces and state armed police, to retake Lalgarh in early June. Maoist leader Kishenji claimed in an interview that the mass Naxalite movement in Lalgarh in 2009 was aimed at creating a "liberated zone" against "oppression of the establishment Left and its police". He stated this had given the Naxalites a major base in West Bengal for the first time since the Naxalite uprising in the mid-1970s and that "We will have an armed movement going in Kolkata by $2011 "$.

\section{Recent Violence In Jangalmahal}

In fact, West Bengal has witnessed a dramatic spurt in Maoist-related fatalities in 2010. According to available data, 425 people, including 328 civilians, 36 security forces personnel and 61 Maoists, including cadre of the Maoist-backed People's Committee Against Police Atrocities, were killed in West Bengal in 2010 till December 26, as against 158 people, including 134 civilians, 15 security forces personnel and nine Maoists killed in the State in 2009.

With this, West Bengal has now earned the dubious distinction of recording the highest Maoist-related fatalities in 2010, dislodging Chhattisgarh which had topped the list since 2006. The intervening years have seen an extraordinary rise in Maoist-related fatalities in West Bengal, from just six in 2005, through 24 in 2008, and up to 158 and 418 people, respectively, in 2009 and 2010.

Security forces fatalities have also risen to 36 in 2010, from 15 in 2009, even as 61 Maoists were killed, as against nine in 2009 , reflecting increasing direct confrontation between the forces and the Maoists. The State witnessed 14 major incidents (involving three or more casualties) through 2010. The Maoists were also involved in at least 25 cases of landmine explosions, 18 incidents of arson, and two incidents of abduction (an overwhelming majority of abduction cases go unreported because of fear of the Maoists). The Maoists also executed seven 'swarming attacks' involving a large number of their armed cadre in 2010, as against eight such attacks in 2009.

Fatalities dropped precipitously after Mamata Banerjee was sworn in as Chief Minister (May, 2011), after the TMC swept the elections, and a collusive arrangement with the Maoists was put in place, resulting in the suspension of operations against the rebels by the State Police. Unsurprisingly, the arrangement did not last, as the Maoists quickly began to target TMC cadres in their areas of dominance, and Banerjee was forced to order the resumption of operations against the Maoists after a succession of high profile killings of TMC leaders. The Security Forces (SFs) delivered a body blow against the Maoists, with the killing of Maoist politburo member Mallojula Koteswara Rao aka Kishanji, on November 24, 2011. As the SFs followed through with a number of other successes, including key arrests and surrenders, Maoist violence in West Bengal ground to a near complete halt, with just four fatalities recorded in the partial data collected by the South Asia Terrorism Portal (SATP), through 2012 (till December 16), including two civilians and two Maoist cadres. 53 persons (41 civilians, two SF personnel and 10 Maoists) were killed in the State in 2011. The State has not recorded any major incident (involving three or more fatalities) in 2012, as against three such incidents in 2011.

Fatalities in Left-wing Extremist Violence in West Bengal: 2005-2012

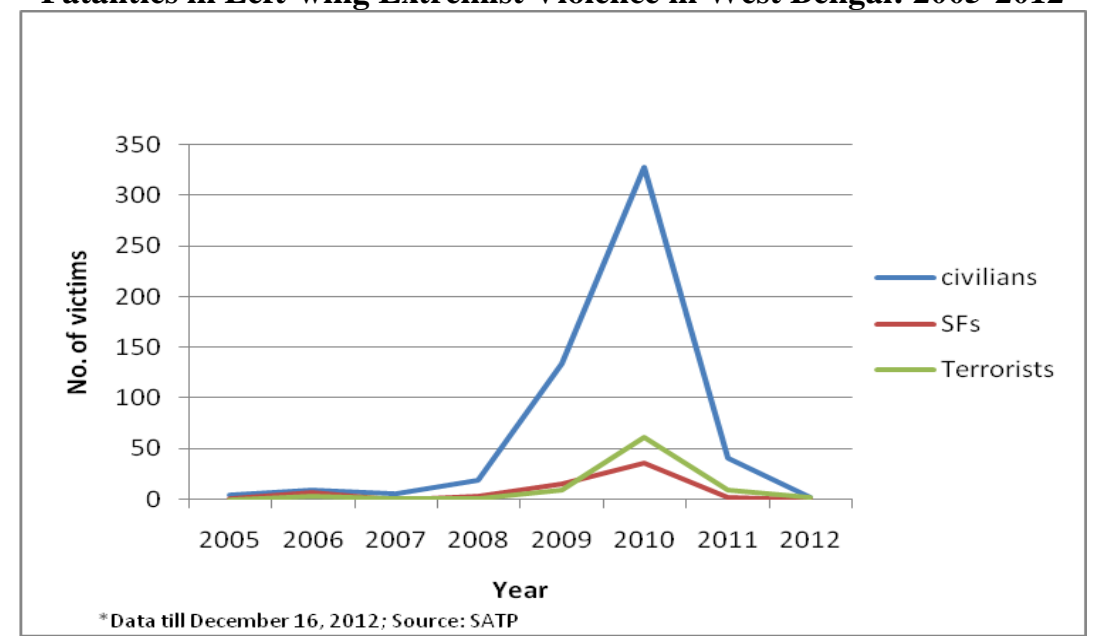




\section{A. Economic Deprivation}

\section{Causes Of Dissatisfaction}

The districts that comprise the Red Corridor are among the poorest in the country. Bihar, Jharkhand and Orissa are among the poorest states in the country. Other areas encompassed by the Red Corridor, such as Chattisgarh state and the Telengana region of Andhra Pradesh, are also either impoverished or have significant economic inequality, or both. The picture of jangalmahal in West Bengal is not exceptional. The region is backward in respect of income, literacy and health. According to the Human Development Report, HDI of West Bengal is 0.625 where in Bankura and Purulia it is 0.52 and 0.45 respectively which possess $11^{\text {th }}$ and $16^{\text {th }}$ rank among the nineteen districts of West Bengal. But in extremely Maoist influenced almost forty blocks (really Jangalmahal) in Bankura, Purulia and West Midnapore District the scenario is really miserable.

Earlier, it has been touched upon that the Maoist dominated blocks are situated in remote areas. There is lack of fertile agricultural land and most of the poor local tribes are landless. Most of them suffer from acute poverty. As a result they maintain their life as agricultural labour. The only means of livelihood of the tribal people in the forest cover areas like Banspahari, Belpahari, Bhulavada and Kankrajhor of West Midnapore is to collect the forest resource. From the forest the women have to gather wood, Kendu leaves, Sal leaves and 'Dudhi Lata' (a kind of vine which is used for binding). They have to sell these at such a cheap rate that by this the can't be able to maintain their daily life. A report says that one hundred 'Dudhi Lata' is sold only at Rupees seven and a bundle of wood at rupees five only. Daily income of the people of the very areas is less than rupees thirty to thirty five. Considered from this point of view they can be included in the list of BPL as declared by Planning Commission. Again, the Joint Security Force has created another problem for the women who collect forest resource from the jungle. Allegations have been raised against the security force that they are doing misconduct with the tribal women.

It is a matter of regret that the Jangalmahal though rich in natural resources the government is not wholehearted as to the development of the areas. Regarding this, the attitude of the State Government and Central Government is the same. But there are golden possibilities of developing agro-based industry which can be favourable for local economic development. This kind of industry can be set up with small capital, investment and land. But day after day their economic state remained unchanged and they have become the victims of the heinous politics. According to GOWB Statistical Abstract $12.7 \%$ male and $51 \%$ female are marginal workers in West Bengal where it is $26.6 \%$ and 67.4\% in Purulia and $18.1 \%$ and $63.2 \%$ in Bankura District [6].

As their poverty is increasing incessantly their future generation is bound to face the same crisis. A report says, at present $20.4 \%$ child of West Bengal suffers from malnutrition where it is $21 \%, 23.6 \%$ and $25.6 \%$ in Purulia, Bankura and West Midnapore Districts respectively [7].

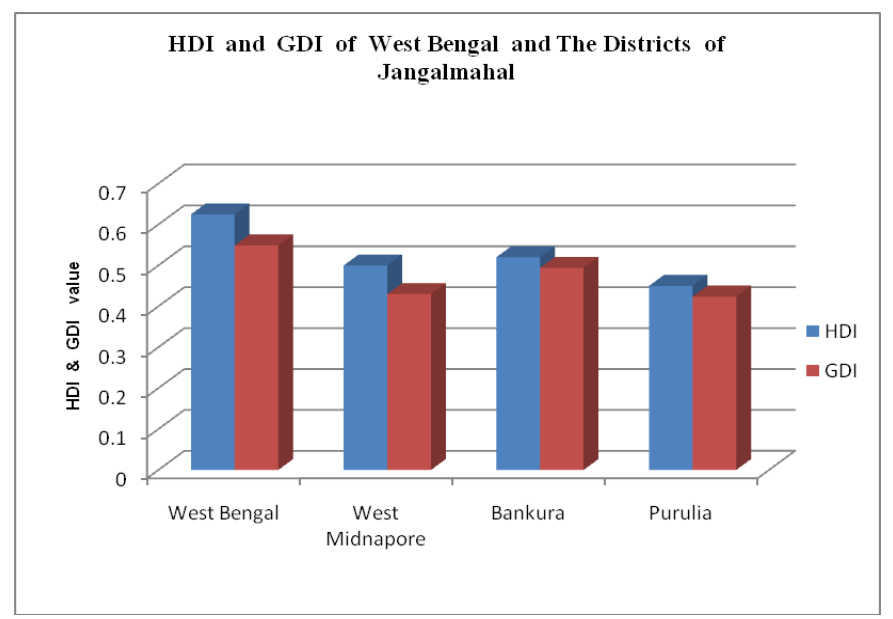

West Bengal Human Development Report

\section{B. Social Injustice}

Earlier it has been mentioned that in remote blocks dominated by the Maoist, of total population $40-50 \%$ is tribal population. For several thousand years, they are found persecuted and deprived by the exterior rulers. This type of deprivation and persecution reached the highest point in the British period. Indeed, the movement of the tribes e.g. the Santal (1855 A.D), the movement of Koles 
(1832 A.D), the movement of Mundas (1895-1901 A.D) sowed its seed. The famous Santal Movement (1855 A.D) or 'Hul' [8] was flourished on the basis of major two demands-----

a) Land and Language Hul (Hasa ar Bhasa Hul) :

Land is sacred to the Adivasis as they have a spiritual relationship with the same; it is indispensible for the life and livelihood of the Adivasis. Similarly, language is a vital instrument for the empowerment of a community. It upholds the socio-cultural identity of a community. Hence a community without land and language is destined to be extinct one day. Santals/Adivasis are being continuously dispossessed from their land, forests and other natural resources.

b) Hul for Self-Governance (Strengthen Manjhi-Pargana System) :

Manjhi Pargana System - the traditional institutions of self-governance has to be empowered socio-politically and economically to fulfil the main objectives of Santal Hul i.e. empowerment of selfgovernance.

But this movement against the British ruler could not be unified due to various reasons. Even after independence (1947) they lacked in leadership by virtue of which they could raise their voice and start movement as to their social demand, status and identity. Even in the reign of Left Front in West Bengal (1977-2010) no effort on the part of government was made to bring them to mainstream. The establishment of 'Adibasi Bikas Porisad' (a committee for tribal development) was not conducive to the development of their social identity. Even to preserve their 'Social Space' they have realised that the so-called political parties of mainstream will never fulfil their justly demands. What we mean by Maoist movement is partly political, and most of it is social and cultural in nature[9].

\section{Political Hypocrisy}

After independence, caste-based politics started in full swing in India. The national and regional political parties, in order to satisfy their narrow political interest they always use the minorities, tribes and other downtrodden class. But after the election is over they totally forget their loud sounding promises. Regarding social and economic development of the tribes they did nothing so far. In West Bengal 'Paschimanchal Unnon Mantrak' (Western Region Development Ministry) was formed by the former Left-Front Govt. to study the problems and development of the Jangalmahal. A cabinet minister is also there to supervise the concerned affairs. In as much as the aforesaid ministry is administered by the existing ruling party, the tribes have no genuine representative presenting the burning problems of the poverty-stricken tribes. Thus, for last several years their discontent on the Left front rulers increased beyond measure. It is reported that during that period many party workers of Left Front were killed by the Maoist. Under this situation, in the recent Assembly Election (2011) the Jangalmahal along with the rest of West Bengal was longing for a radical change. Ultimately Left Front was miserably defeated as expected and Trinomul Congress- Congress Alliance came in power. At this time the people of Jangalmahal cherished high aspiration and expectation to the new government. But it is not possible for new government to fulfill their demands immediately. The deprived people are now realising that even there is a change of political power but their fate will remain unchanged. Thus their target has been changed to kill the local TMC leaders instead of Left Front party workers. The very recent killing of Rabindronath Mishra and Lalmohan Mahato, the supports of TMC can be cited in this regard. Undoubtedly the situation will be more critical in near future.

Now it is quite relevant to focus on recent Far-Left political movement (Maoist) in west Bengal. The Maoist movement of the day differs ideologically and methodologically from that of the Naxalist Movement in 1970's. The Naxalist Movement had a prominent leadership and outline which helped them in being widespread. Many intellectuals inclusive of mainstream had their support and sympathy to the followers of the movement. But now in West Bengal the Maoist activities are confined to the western part of the state only. Besides this, their political leadership is clouded with smoke. Naturally a question regarding their leadership has risen up. Many people with narrow interest are joining the Maoist movement and in claiming themselves as dedicated leader are spreading confusion. Their immoral and unreliable activities are making non-political common people disregard to them. As a result the people of Jangalmahal are being misguided.

\section{Demand For Cultural Identity}

The tribal communities are very conscious as to the preservation and reservation of their cultural identity. It is nothing but a conspiracy against their culture and heritage in the name of bringing them to the mainstream. Actually it is a subtle plan to root out their culture. It should not be forgotten that the tribal culture is an ancient trend of Indian Culture. Now it is almost dead as a 
result of deprivation. No government sincerely tried to survive the most valuable cultural trend of ancient India. It is a fact that the basis of the reorganisation of the states is language as well as culture. Discontent and agitation in the various parts of India are growing up gradually. It is due to not following this basic formula. Before 1956, Purulia had its inclusion in Jharkhand (former Bihar).

It is a matter of wonder that the tribal language had no written form. Decades of struggle by Santals/Adivasi have brought Santali language within the 8th Schedule of the Constitution of India on the 22nd of December 2003. However, till today Santali language has not received its due respect as is given to other languages (like Bengali, Oriya, Assamese etc.) in the 8th Schedule of the Constitution. After a long discussion on it 'Alchiki' script has been selected as the written form of Santali Language. But Santali Language has not yet been introduced in the maximum schools of Jangalmahal. Few years ago teacher appointment for Santali Language by West Bengal School Service Commission has began in West Bengal. But it is a matter of despair that the recruitment is practically meagre. Thus they are bound to sit for competitive examination in State or National level in selecting either Hindi or Bengali or English. Keeping the language problem aside, it is reasonable to say that their dance, song and art are also neglected. For example, the 'Chou' artists are about to be extinguished in Purulia.

\section{In Quest Of Peace \\ Rectification of the traditional concept of 'Mainstream'}

'Mainstream' is a confusing term and firstly it must be modified. The government and the intellectual groups are of the opinion that the 'Maoist' (who believe in terrorism) [10] have to be turned back to the mainstream. In this connection the vital question to be arisen: Which stream is 'main'? Is it the only urban culture of upper caste? Being inspired by this wrong notion the upper caste all along neglected the thought and culture of the ancient race. It should not be forgotten that Indian Culture as a whole is the result of synthesis------ reconciliation of all races e.g. Aryan, NonAryan (Adibasi or Tribe), Sak-Hun-Pathan-Mughal and the British. Vincent Smith, the famous British historian called India 'Ethnological Museum' and the 'Epitome of the World'. So to preserve Indian culture and heritage 'unity in diversity' must be preserved impartially. This means that both Aryan and non-Aryan Culture should be respected equally because every race has a sentimental tendency to his 'Cultural Space'. The tribes are not exceptional to this. When the people of Jangalmahal will find out their 'Cultural Space' their inferior complexity will be vanished.

Up to now, the tribes acquired no confidence in the government. To start the developmental works in the tribal areas it is necessary for the government to acquire their confidence. Until the process is started the government can never expect for any co-operation form the tribes. On the part of the government the following steps have to be taken---------

a) Efforts to develop their mother tongue and culture and to create scope for competitive examination in Santali Language. Governments (Central and State) should promote the language to be used for Radio \& T. V. broadcasts, Newspapers, Magazines production and dissemination and its use in legal procedures in courts.

b) To ensure their traditional right to forest resource. In lieu of taking heavy industrial project it is necessary to develop their economy consistent with their mentality (i.e. development of animal husbandry and agro-based as well as forest resource based industry)

c) In case of govt. employment the local people should have preference in the vacancy of Police, B.D.O etc. As a result the communication with local people will be easy.

d) The govt. has to discharge their full responsibility for the education and health of families included in the BPL list in Jangalmahal. Govt. should also facilitate the formation of Santali academies for literary and cultural development and also institute Award and Rewards for outstanding Santal writers, scholars, dramatists etc.

e) Not to politicise the problems of the Jangalmahal.

\section{Opinion of the non-political scholars}

The political and administrative measures hitherto taken in order to solve the problems of the Jangalmahal are not successful. Recently, some intellectuals from Kolkata are playing the role of intermediary in this regard. As the very personalities are now directly involved in politics and their influence to the local people is not up to the mark, so acceptable formula in connection with this can not be expected from them. For going deep into the problems and their solution the opinion of the nopolitical personalities is urgent now. Behind Maoist problem lie geographical, social, ethnological and political causes. So to solve the problems, the distinct outlooks of the geographer, sociologist, anthropologist and the political philosophers are of course considerable. Thus the scientific and permanent solution of the so-called problems may be possible. 
Firm stand against the disguised Maoist

At present the self-claimed Maoist leaders have created terror in the Jangalmahal. Not caring for law and order, they have engaged themselves in destructive activities like killing, rape and looting. Central force and State police have to be employed there to launch joint action but at the same time carefulness is necessary so that the innocent common people may not be harassed.

\section{In Concluding Statement}

It has already been said that only political and administrative efforts are not sufficient for solving the problems. What is now urgent for this is scientific and realistic approach and it is not possible by magic, but by logic. The Govt. should take a definite policy (either extremist or moderate) to face the Maoist challenge. On the other hand, if their efforts are foiled then like the demand for Gorkhaland in the North of West Bengal, the demand for a separate state in the Jangalmahal may also arise in course of time.

\section{Bibliography And References}

[1]. Gupta, D.K; (2008) "Understanding terrorism and political violence: the life cycle of birth, growth, transformation, and demise", Routledge, U.K (p-178)

[2]. Gilly, T.A, Gilinskiy, Y. \& Sergevnin, V.A eds. (2009), "The ethics of terrorism: innovative approaches from an international perspective (17 lectures)", Charles C Thomas Publisher, USA

[3]. Singh, P. (1999 "The Naxalite Movement in India” Rupa \& Co., New Delhi (p. 101.)

[4]. Jawaid, S. (1979), "The Naxalite Movement in India: Origin and Failure of the Maoist Revolutionary Strategy in West Bengal, 1967-1971", Associated Pub. House

[5]. Samanta, A.K. (1984)“ Left extremist movement in West Bengal: an experiment in armed agrarian struggle”, Firma KLM

[6]. Mallick, R. (2007)“Development Policy of a Communist Government: West Bengal Since 1977”, Cambridge University Press, (p12)

[7]. West Bengal Human Development Report (2007): Government of West Bengal

[8]. Philip, Ekka. (2003), "Tribal Movements: A Study in Social Change" Kailash Paper Conversion Pvt. Ltd., Ranchi.

[9]. Dobhal, H. and Jacob, M. eds. (2012) "Rugged Road to Justice: A Social Audit of State Human Rights Commissions in India", vol. 1; Socio Legal Information Cent, New Delhi (p. 66-67)

[10]. Frey, R. G. and Morris, C. W. (1991), "Violence, Terrorism, and Justice" Cambridge University Press, New York 